\title{
PENGEMBANGAN PERANGKAT MODEL PEMBELAJARAN DISCOVERY LEARNING BERBASIS LITERASI NUMERASI UNTUK MENINGKATKAN PEMAHAMAN KONSEP MATEMATIKA
}

\section{DEVELOPMENT OF DISCOVERY LEARNING TOOLS BASED ON NUMERICAL LITERACY TO IMPROVE MATHEMATICS CONCEPT OF UNDERSTANDING}

\author{
RUMIYATUN \\ SMPN 45 Jakarta
}

\begin{abstract}
Received: May 07, 2021

Revised: May 10, 2021

The research aims to produce a set of learning tools, including lesson plans and students' sheets using a discovery learning model based on literacy. The research was conducted at SMPN 249 West Jakarta academic year 2019-2020 and the eighth grade students as the objects. This is a developmental research using ADDIE models. The Data collection is using questionnaires, observations, tests, and documents. The results showed that the learning device was feasible based on the validity aspect with the lesson plans value of 4.3 or very good and students' sheet of 4.2 or good category. Furthermore, from the practical aspect, the students' responses were 3.6 or good category and the implementation of learning was $86 \%$. The aspect of effectiveness showed an increase in the complete understanding of mathematical concepts from 36\% pretest and $77 \%$ posttest. These improvements include the ability to change the configuration of the number pattern object and determine the formula for the nth term. The conclusion of this study is that the discovery learning model based on numeracy literacy that was developed is feasible to use and can improve understanding of mathematical concepts in number patterns.
\end{abstract}

\begin{abstract}
Abstrak. Pemahaman konsep pola bilangan masih tergolong rendah, peserta didik belum dapat memahami bagaimana mengubah konfigurasi objek menjadi pola bilangan. Penelitian ini bertujuan untuk menghasilkan perangkat pembelajaran, meliputi rencana program pembelajaran (RPP) dan lembar kegiatan peserta didik (LKPD) dengan menggunakan model discovery learning berbasis literasi numerasi. Penelitian dilakukan di SMPN 249 Jakarta, dengan melibatkan peserta didik kelas VIII. Penelitian ini adalah penelitian pengembangan menggunakan model ADDIE (Analysis, Design, Development, Implementation and Evaluation). Pengumpulan data menggunakan kuesioner, observasi, tes, dan dokumen. Hasil penelitian menunjukkan perangkat pembelajaran layak berdasarkan penilaian aspek kevalidan dengan rata-rata skor RPP sebesar 4,3 atau sangat baik dan LKPD sebesar 4,2 atau kategori baik. Selanjutnya dari aspek kepraktisan diperoleh rata-rata respon peserta didik sebesar 3,6 atau kategori baik dan keterlaksanaan pembelajaran diperoleh rata-rata sebesar $86 \%$. Aspek keefektifan menunjukkan peningkatan ketuntasan pemahaman konsep matematika dari pretes sebesar 36\% dan postes sebesar $77 \%$. Peningkatan tersebut meliputi, kemampuan mengubah konfigurasi objek pola bilangan dan menentukan rumus suku ke-n. Simpulan penelitian ini adalah bahwa perangkat pembelajaran model pembelajaran discovery berbasis literasi numerasi yang dikembangkan layak digunakan dan dapat meningkatkan pemahaman konsep matematika pada pola bilangan perangkat pembelajaran model discovery, literasi numerasi, pemahaman konsep
\end{abstract}

Keywords: $\quad$ discovery learning tools, numerical literacy, concept of understanding

Kata kunci:

$\left(^{\star}\right)$ Corresponding Author: rumiarum249@gmail.com

How to Cite: Rumiyatun. (2021). Pengembangan Perangkat Model Pembelajaran Discovery Learning Berbasis Literasi Numerasi untuk Meningkatkan Pemahaman Konsep Matematika. Jurnal Lingkar Mutu Pendidikan, 18 (1), 91-98. https://doi.org/10.54124/ jlmp.v18i1.19

\section{PENDAHULUAN}

Kompetensi matematika peserta didik terkait pemahaman konsep pola bilangan merupakan kompetensi esensial yang berguna untuk mendukung bidang ilmu lain dan masalah dalam kehidupan sehari-hari. Salah satu cara untuk meningkatkan kemampuan pemahaman konsep matematika peserta didik adalah dengan pemilihan model pembelajaran yang dapat mengajak dan menuntun 
peserta didik menemukan kembali suatu konsep matematika sehingga memberikan pemahaman yang lebih terhadap materi tersebut. Untuk itu guru perlu membuat perangkat pembelajaran dengan model pembelajaran yang dapat meningkatkan kemampuan pemahaman konsep matematika. Perangkat pembelajaran merupakan bagian yang sangat penting dalam keberhasilan dalam mencapai suatu tujuan pembelajaran.

Namun kenyataan yang terjadi, berdasarkan hasil observasi dan wawancara yang dilakukan di SMP Negeri 249 Jakarta, guru masih kesulitan dalam menyusun perangkat pembelajaran, berupa Rencana Program Pembelajaran (RPP) dan Lembar Kerja Peserta Didik (LKPD) dengan model pembelajaran yang sesuai materi yang akan dipelajari serta memasukan unsur literasinya. Pada akhirnya menggunakan RPP dan LKPD yang disusun orang lain dan tidak tervalidasi.

Dengan kondisi tersebut, sangat mungkin guru akan mengalami masalah antara lain: (1) Guru kurang siap dalam melakukan pembelajaran di kelas, (2) Dalam menyajikan materi guru hanya terpaku pada buku paket (3) Peserta didik mengalami pembelajaran yang tidak bermakna, karena peserta didik tidak dilibatkan langsung sehingga pengetahuan dan pemahaman yang mereka peroleh hanya bersifat ingatan jangka pendek.

Kebanyakan pembelajaran matematika di Indonesia masih fokus pada perhitungan (drill), peran guru lebih dominan (teacher-centered), kemahiran dalam mengemukakan pendapat (reasoning), pemahaman konsep dan bagaimana melakukan pemecahan masalah kehidupan sehari-hari pada peserta didik belum banyak didorong dan diberikan kesempatan. Hal tersebut mengakibatkan rendahnya kemampuan literasi numerasi di Indonesia, diketahui dari hasil tes PISA pada tahun 2015 dan TIMSS tahun 2016. Hasilnya tes PISA Indonesia menempati urutan yang lebih rendah dibanding negara Vietnam dengan nilai matematika 387 dari nilai rerata 490 sedangkan nilai matematika Indonesia dalam TIMSS adalah 395 dari nilai rerata 500 (GLN 2017). Pemecahan masalah pada matematika merupakan bagian dari literasi numerasi. Dengan demikian pemecahan masalah matematika membutuhkan pemahaman konsep matematika yang memadai.

Untuk mengatasi masalah-masalah tersebut perlu dikembangkan perangkat pembelajaran matematika yang dengan model pembelajaran yang melibatkan peserta didik secara langsung untuk menemukan konsep dari suatu materi dan berbasis literasi numerasi. Salah satu model pembelajaran yang sesuai adalah discovery learning berbasis literasi numerasi.

Berdasarkan latar belakang tersebut, rumusan masalah dari penelitian ini adalah, "Bagaimana pengembangan perangkat model pembelajaran discovery learning berbasis literasi numerasi untuk meningkatkan pemahaman konsep matematika?" Penelitian ini bertujuan antara lain untuk mengetahui proses dan kualitas pengembangan perangkat model pembelajaran discovery learning berbasis literasi numerasi dan untuk mengetahui peningkatan pemahaman konsep matematika menggunakan perangkat model pembelajaran discovery learning berbasis literasi numerasi pada peserta didik kelas VIII SMPN 249 Jakarta.

Manfaat dari penelitian ini membantu peserta didik agar lebih aktif dan kreatif untuk mengembangkan kemampuan, menerapkan pengetahuan, melatih keterampilan, memproses sendiri dengan bimbingan guru sehingga memperoleh pemahaman yang lebih, tidak hanya sebatas ingatan saja. Bagi guru sebagai bahan masukan supaya kedepannya dapat lebih mencermati dalam menyusun perangkat pembelajaran sehingga tujuan yang diharapkan dapat tercapai dengan baik. Sedangkan manfaat penelitian ini bagi sekolah sebagai bahan pertimbangan dalam mengambil keputusan demi kemajuan kualitas pembelajaran.

Perangkat pembelajaran adalah segala sesuatu atau beberapa persiapan yang disusun oleh guru baik secara individu maupun berkelompok agar pelaksanaan dan evaluasi pembelajaran dapat dilakukan secara sistematis dan memperoleh hasil seperti yang diharapkan, sedangkan perangkat pembelajaran yang dimaksud terdiri atas Analisis Pekan Efektif, Program Tahunan, Program Semester, Silabus, RPP dan KKM.

Dalam Permendikbud No. 65 Tahun 2013 tentang tentang Standar Proses Pendidikan Dasar dan Menengah, disebutkan bahwa penyusunan perangkat pembelajaran merupakan bagian dari perencanaan pembelajaran. Sedangkan menurut Rusman (2013,5), RPP dijabarkan dari silabus untuk mengarahkan kegiatan belajar peserta didik dalam upaya mencapai kompetensi dasar. 
RPP tidak berdiri sendiri, namun harus disertai media sebagai alat bantu, salah satunya LKPD yang dibuat sesuai dengan kegiatan pembelajaran. Tujuan yang terdapat pada RPP dapat digunakan sebagai penuntun oleh peserta didik dalam memahami konsep materi yang dipelajari.

LKPD (student work sheet) adalah lembaran-lembaran berisi tugas yang harus dikerjakan oleh peserta didik, biasanya berupa petunjuk, langkah-langkah untuk menyelesaikan suatu tugas dengan mengikuti dan mengacu kompetensi dasar (KD). Ada beberapa model pembelajaran yang terdapat pada Kurikulum 2013 dan dapat diterapkan, salah satunya model discovery learning. Model discovery learning mengembangkan cara belajar peserta didik aktif dengan menemukan sendiri, menyelidiki sendiri, maka hasil yang diperoleh akan tahan lama dalam ingatan. (Salmon 2012, 4)

Menurut Kemdikbud (2013) ada beberapa kelebihan dan kelemahan model discovery learning. Kelebihan model discovery learning antara lain: 1) Membantu peserta didik dalam meningkatkan keterampilan-keterampilan serta proses-proses kognitif. 2) Memungkinkan peserta didik berkembang dengan cepat dan sesuai dengan kecepatannya sendiri. 3) Meningkatkan tingkat penghargaan peserta didik kerena ada unsur berdiskusi. 3) Menimbulkan rasa senang pada peserta didik karena tumbuhnya rasa menyelidiki dan berhasil. 4) Membantu peserta didik menghilangkan keragu-raguan karena mengarah pada kebenaran yang final dan tertentu atau pasti. Kekurangan model discovery learning antara lain: 1) adanya pendapat bahwa metode memerlukan kesiapan berpikir peserta didik untuk belajar. Sebagian peserta didik yang kurang siap, akan mengalami kesulitan berpikir dalam menghubungan konsep-konsep yang tertulis ataupun secara lisan. 2) Membutuhkan waktu yang lama untuk menemukan teori atau memecahkan masalah. 3) Harapan-harapan yang terkandung dalam model discovery learning dapat buyar berhadapan dengan peserta didik dan guru yang telah terbiasa dengan cara-cara belajar yang lama. 4) Model Discovery Learning Discovery lebih ditujukan untuk menumbuhkan pemahaman, dan tidak memberikan perhatian pada pengembangan konsep keterampilan dan emosional. 5) Tidak menyediakan kesempatan untuk berpikir yang ditemukan oleh peserta didik karena telah dipilih terlebih dahulu oleh guru.

Selain model pembelajaran yang berpusat kepada peserta didik, kurikulum 2013 mengharuskan guru memasukkan unsur literasi numerasi dalam kegiatan pembelajaran. Literasi numerasi merupakan kemampuan untuk menggunakan konsep bilangan dan keterampilan berhitung dalam keseharian. Dalam konteks Gerakan Literasi Nasional (Kemdikbud 2017) menyatakan bahwa Literasi numerasi merupakan pengetahuan dan kecakapan untuk (a) menggunakan berbagai macam angka dan simbolsimbol yang terkait dengan matematika dasar untuk memecahkan masalah praktis dalam berbagai macam konteks kehidupan sehari-hari dan (b) menganalisis informasi yang ditampilkan dalam berbagai bentuk (grafik, tabel, bagan, dsb) lalu menggunakan interpretasi hasil analisis tersebut untuk memprediksi dan mengambil keputusan.

Literasi numerasi adalah bagian dari matematika, dengan komponen yang digunakan bersumber dari cakupan matematika pada Kurikulum 2013, seperti terlihat dalam tabel 1.

Tabel 1. Komponen Literasi Numerasi dalam Cakupan Matematika Kurikulum Tahun 2013

\begin{tabular}{ll}
\hline Komponen Literasi Numerasi & Cakupan Matematika Kurikulum 2013 \\
\hline Mengestimasi dan menghitung dengan bilangan bulat & Bilangan \\
Menggunakan pecahan, desimal, persen, dan perbandingan & Bilangan \\
Mengenali dan menggunakan pola dan relasi & Bilangan dan Aljabar \\
Menggunakan penalaran spasial & Geometri dan Pengukuran \\
Menggunakan pengukuran & Geometri dan Pengukuran \\
Menginterpretasi informasi statistik & Pengolahan data \\
\hline
\end{tabular}

Perangkat pembelajaran yang tepat merupakan jembatan penuntun bagi peserta didik dalam kegiatan pembelajaran terutama pada saat memahami konsep matematika. Konsep merupakan kondisi utama yang diperlukan untuk menguasai kemahiran. Diskriminasi dalam proses kognitif berdasarkan ciri-ciri dan sekumpulan stimulus dari objektifnya. (Djamarah and Zain 2010, 17)

Sedangkan konsep matematika menurut Budiono dalam (Virgana 2016) adalah segala yang berwujud pengertian-pengertian baru yang bisa timbul sebagai hasil pemikiran, meliputi definisi, 
pengertian, ciri khusus, hakikat dan inti/isi dari materi matematika. Jadi penguasaan konsep merupakan modal utama dalam menyelesaikan persoalan/masalah matematika.

Beberapa penelitian terdahulu melaporkan, bahwa pengembangan perangkat pembelajaran yang disesuaikan dengan kondisi dan materi menyebabkan pembelajaran matematika menjadi lebih mudah bagi peserta didik dan pembelajaran menjadi lebih bermakna karena pembelajaran diawali dari hal yang mereka ketahui sebelumnya. Demikian halnya dengan literasi numerasi membutuhkan pengetahuan matematika yang dipelajari dalam kurikulum sekolah. Namun demikian, pembelajaran matematika sendiri belum tentu menumbuhkan kemampuan numerasi jika materi ajarnya tidak dirancang untuk hal itu (Pangesti 2018).

\section{METODE PENELITIAN}

Penelitian ini menggunakan model penelitan pengembangan ADDIE (Analysis, Design, Development, Implementation and Evaluation), terdiri dari lima tahap pengembangan model yaitu tahap analisis, desain, pengembangan, implementasi dan evaluasi (Sugiyono. 2015)

Penelitian ini dilaksanakan pada 22 Juli sampai dengan 8 Agustus 2019 sebanyak 4 pertemuan tatap muka dan 1 kali pertemuan untuk tes hasil belajar. Adapun subjek uji coba pada penelitian ini adalah guru dan peserta didik kelas VIII SMP Negeri 249 Jakarta.

Prosedur pengembangan dimulai dengan tahap Analysis yaitu tahap penelitian pendahuluan untuk memperoleh informasi yang berhubungan dengan masalah yang terjadi dan produk yang akan dikembangkan untuk menjawab permasalahan tersebut. Pada tahap ini juga dilakukan tinjauan pustaka mengenai konsep dan teori yang berkaitan dengan discovery learning, literasi numerasi dan pemahaman konsep matematika sebagai dasar untuk menyusun indikator dan kajian mengenai teori sehingga diperoleh pembelajaran yang lebih bermakna. Hal lain yang juga dilakukan adalah analisis dan telaah kurikulum matematika SMP kelas VIII sebagai landasan untuk menentukan KI dan KD yang akan digunakan dalam pengembangan perangkat pembelajaran.

Tahapan berikutnya adalah tahap Design yaitu perancangan produk yang mencakup penyusunan RPP dan LKPD dengan model pembelajaran discovery berbasis literasi numerasi serta penyusunan instrumen penilaian hasil belajar yang terdiri dari pretes dan postes dan angket respon peserta didik.

Kemudian tahap Development yaitu pengembangan produk perangkat pembelajaran berupa RPP dan LKPD dengan model pembelajaran discovery berbasis literasi numerasi dan penyusunan perangkat penilaian berupa lembar penilaian RPP, lembar penilaian LKPD, angket respon peserta didik, lembar observasi keterlaksanaan kegiatan pembelajaran, dan tes hasil belajar (soal pretes dan postes). Pada tahap ini validasi dilakukan oleh ahli. Jika hasil analisis produk perangkat pembelajaran dinyatakan layak tanpa catatan revisi, maka produk awal dapat langsung diujicobakan. Jika hasil dinyatakan layak digunakan dengan revisi, maka dilakukan revisi seperti yang disarankan ahli untuk menghasilkan produk awal yang layak digunakan.

Selanjutnya tahap Implementasi yakni melakukan uji coba lapangan untuk mengetahui kualitas kepraktisan dan keefektifan produk yang dikembangkan. Ujicoba dilakukan di kelas VIII SMP Negeri 249 Jakarta.

Tahap Evaluation yang merupakan tahap akhir dilakukan dengan analisis hasil uji coba lapangan. Apabila hasil analisis telah memenuhi kriteria, maka produk tersebut adalah produk akhir, jika hasil analisis belum memenuhi kriteria, maka dilakukan revisi produk kembali sehingga diperoleh produk yang valid, praktis, dan efektif.

Teknik dan instrumen pengumpulan data pada penelitian ini menggunakan dua teknik, yaitu teknik tes dan teknik non tes. Teknik pengumpulan data dengan tes menggunakan instrumen (pretes dan postes), sedangkan teknik pengumpulan data non tes menggunakan lembar validasi produk, lembar observasi keterlaksanaan pembelajaran dan angket respon peserta didik. Lembar validasi digunakan untuk mengukur kevalidan produk berupa perangkat pembelajaran (RPP dan LKPD). Instrumen tes (pretes dan postes) digunakan untuk mengukur tingkat pemahaman konsep peserta didik sekaligus mengukur kefektifan perangkat pembelajaran. Sedangkan lembar observasi pembelajaran dan angket respon peserta didik digunakan untuk mengukur kepraktisan perangkat pembelajaran. 
Teknik analisis data dalam penelitian ini meliputi teknik analisis data kuantitatif dan kualitatif. Hasil analisis data akan digunakan untuk menentukan kualitas perangkat pembelajaran yang ditinjau dari aspek kevalidan, kepraktisan, dan keefektifan. Kevalidan perangkat pembelajaran yang dikembangkan diperoleh dari hasil penilaian ahli materi dan ahli media yang dalam hal ini adalah guru matematika yang juga aktif di pusat kurikulum Kemdikbud. Sedangkan Kepraktisan LKPD diperoleh dari hasil angket respon peserta didik dan kepraktisan RPP diperoleh dari hasil lembar observasi keterlaksanaan kegiatan pembelajaran.

Pada penelitian ini pedoman kualitas kevalidan dan kepraktisan perangkat menggunakan klasifikasi interpretasi penilaian seperti pada Tabel 2.

Tabel 2. Kategori kevalidan dan kepraktisan RPP dan LKPD

\begin{tabular}{cc}
\hline Interval & Kriteria \\
\hline $\bar{x}>4,2$ & Sangat baik \\
$3,4<\bar{x} \leq 4,2$ & Baik \\
$2,6<\bar{x} \leq 3,4$ & Cukup \\
$1,8<\bar{x} \leq 2,6$ & Kurang \\
$\bar{x} \leq 1,8$ & Sangat kurang \\
\hline
\end{tabular}

Analisis kepraktisan perangkat diperoleh berdasarkan analisis data hasil lembar penilaian guru, lembar penilaian peserta didik, dan lembar observasi keterlaksanaan pembelajaran. Skor penilaian guru terhadap perangkat pembelajaran (RPP dan LKPD), skor penilaian peserta didik terhadap perangkat pembelajaran (LKPD), dan persentase keterlaksanaan pembelajaran menggunakan acuan sebagai berikut.

Presentase skor lembar observasi $=\frac{\text { skor yang diperoleh }}{\text { skor maksimal }} \times 100 \%$

Perangkat pembelajaran yang dikembangkan dikatakan praktis jika penilaian guru, penilaian peserta didik, dan observasi keterlaksanaan pembelajaran minimal dalam kategori "baik". Kemudian persentase skor yang diperoleh dikonversikan ke dalam tabel 3.

Tabel 3. Kategori aspek kepraktisan

\begin{tabular}{cl}
\hline Presentase (\%) & \multicolumn{1}{c}{ Kriteria } \\
\hline $90 \leq p \leq 100$ & Sangat baik \\
$80 \leq p<90$ & Baik \\
$70 \leq p<80$ & Cukup \\
$60 \leq p<70$ & Kurang \\
$p<60$ & Sangat kurang \\
\hline
\end{tabular}

Keefektifan perangkat pembelajaran dianalisis dari tes hasil belajar. Dengan langkah-langkah analisis keefektifan perangkat pembelajaran yaitu menghitung nilai yang diperoleh peserta didik, menganalisis apakah peserta didik dinyatakan tuntas atau tidak sesuai dengan KKM. KKM untuk SMP Negeri 249 Jakarta adalah 75 dan menghitung persentase ketuntasan belajar dengan cara, sebagai berikut:

Ketuntasan belajar $=\frac{\text { banyak peserta didik yang tuntas }}{\text { banyak peserta didik yang ikut tes }} \times 100 \%$

\section{HASIL DAN PEMBAHASAN}

Tahap pengembangan perangkat pembelajaran dilakukan sesuai dengan draft yang telah disusun pada tahap perancangan. Tahap pengembangan RPP yang dilakukan berupa, pengembangan RPP, penyuntingan RPP, validasi RPP, dan revisi RPP. Pada tahap ini yang bertindak sebagai validator adalah guru matematika senior, yang telah berpengalaman dan berkecimpung di bidang kurikulum Kemdikbud sebagai juga sebagai validator untuk menyunting dan memvalidasi RPP. Hasil validasi RPP disajikan pada tabel 4. 
Tabel. 4 Hasil Validasi RPP

\begin{tabular}{lll}
\hline Aspek penilaian & Skor & Kriteria \\
\hline $\begin{array}{l}\text { Komponen RPP(identitas, tujuan pembelajaran, PPK, materi, kegiatan } \\
\text { pembelajaran, sumber belajar, dan penilaian) }\end{array}$ & 5 & Sangat baik \\
$\begin{array}{l}\text { Kesesuaian indikator pencapaian kompetensi dengan kompetensi dasar } \\
\text { Kesesuaian materi prasyarat dengan materi yang akan diajarkan }\end{array}$ & 4 & Sangat baik \\
$\begin{array}{l}\text { Kesesuaian kegiatan pembelajaran dengan tahapan pembelajaran discovery } \\
\text { berbasis literasi numerasi dan kecakapan abad 21 }\end{array}$ & 4 & Sangat baik \\
$\begin{array}{l}\text { Langkah-langkah pembelajaran dijabarkan dengan jelas } \\
\text { Kesesuaian perkiraan alokasi waktu dengan kegiatan yang dilakukan baik }\end{array}$ & 4 & Sangat baik \\
$\begin{array}{l}\text { Penggunaan Bahasa sesuai dengan kaidah Bahasa Indonesia yang baik dan } \\
\text { benar }\end{array}$ & 5 & Sangat baik \\
$\begin{array}{l}\text { Bahasa yang digunakan singkat, jelas, dan tidak menimbulkan pengertian baik } \\
\text { ganda }\end{array}$ & 4 & Sangat baik \\
\hline Jumlah & 39 & \\
\hline Rata-rata & 4,3 & Sangat baik \\
\hline
\end{tabular}

Sesuai Tabel 4, rata-rata total skor penilaian ahli terhadap RPP yang dikembangkan adalah 4,3 dengan kriteria "sangat baik", hal ini menunjukkan bahwa RPP yang dikembangkan sudah valid.

Kegiatan pengembangan LKPD yaitu pada aspek kesesuaian dengan pembelajaran discovery berbasis literasi numerasi, penyuntingan LKPD, validasi LKPD, dan revisi LKPD. Beberapa pengembangan LKPD dilakukan pada komponen, antara lain: a) komponen format, b) komponen isi, dan c) komponen bahasa. Selanjutnya menyunting dan memvalidasi LKPD dilakukan dengan bantuan seorang guru matematika senior dan berkecimpung di bidang kurikulum Kemdikbud sebagai validator. Skor hasil validasi LKPD disajikan pada tabel 5.

Tabel 5 Hasil Validasi LKPD

\begin{tabular}{lll}
\hline Aspek penilaian & Skor & Kriteria \\
\hline $\begin{array}{l}\text { Kelengkapan struktur LKPD (judul, petunjuk belajar, kompetensi yang ingin } \\
\text { dicapai, informasi pendukung (ilustrasi dan gambar), langkah mengerjakan } \\
\text { soal, dan tempat kosong untuk menuliskan jawaban. }\end{array}$ & 5 & Sangat baik \\
$\begin{array}{l}\text { Kejelasan format penulisan LKPD (jenis huruf, ukuran huruf, system } \\
\text { penomoran) }\end{array}$ & 5 & Sangat baik \\
$\begin{array}{l}\text { Daya Tarik atas penampilan LKPD (layout, gambar, tabel, diagram, grafik) } \\
\text { Kesesuaian LKPD dengan indikator yang akan dicapai. }\end{array}$ & 3 & Baik \\
$\begin{array}{l}\text { Kesesuaian tugas dengan urutan materi } \\
\text { Kesesuaian tugas dengan pembelajaran discovery berbasis literasi. }\end{array}$ & 4 & Sangat baik \\
$\begin{array}{l}\text { Penggunaan Bahasa sesuai dengan kaidah Bahasa Indonesia yang baik dan } \\
\text { benar. }\end{array}$ & 4 & Sangat baik \\
$\begin{array}{l}\text { Bahasa yang digunakan singkat, jelas, dan tidak menimbulkan pengertian } \\
\text { ganda }\end{array}$ & 4 & Sangat baik \\
Kesederhanaan Bahasa yang digunakan serta kesesuaian Bahasa dengan taraf baik \\
berpikir peserta didik. & 4 & Sangat baik \\
\hline Jumlah & 38 & \\
\hline Rata-rata & 4,2 & Sangat baik \\
\hline
\end{tabular}

Berdasarkan Tabel 5, diperoleh rata-rata total skor penilaian ahli terhadap LKPD yang dikembangkan adalah 4,2 dengan kriteria "sangat baik". Sehingga dapat disimpulkan bahwa Lembar Kegiatan Peserta Didik (LKPD) yang dikembangkan sudah valid.

Angket respon peserta didik digunakan untuk mengetahui kelayakan LKPD berdasarkan aspek kepraktisan. Angket ini diisi oleh 36 peserta didik kelas VIII SMP Negeri 249 Jakarta. Hasil analisis angket respon peserta didik disajikan pada tabel 6. 
Tabel. 6 Hasil Analisis Respon Peserta Didik

\begin{tabular}{llll}
\hline Aspek penilaian & $\mathrm{n}$ & Skor & Kriteria \\
\hline Ketepatan penggunaan bahasa dan kalimat serta penampilan LKPD & 36 & 3,8 & Baik \\
Sikap peserta didik terhadap LKPD & 3,5 & Baik \\
Kemudahan penggunaan dan aktivitas di LKPD & 3,7 & Baik \\
Penggunaan LKPD & 3,7 & Baik \\
Materi LKPD & 3,5 & Baik \\
Jumlah & 18,2 & \\
\hline Rata-rata & 3,6 & Baik \\
\hline
\end{tabular}

Berdasarkan Tabel 6, diperoleh rata-rata total skor respon peserta didik terhadap kelayakan LKPD yang dikembangkan adalah 3,6 dengan kriteria "baik". Hal ini menunjukkan bahwa LKPD yang dikembangkan layak digunakan.

Uji coba perangkat pembelajaran dilaksanakan di SMP 249 Jakarta pada tanggal 22 Juli sampai dengan 8 Agustus 2019 sebanyak 4 pertemuan tatap muka dan 1 kali pertemuan untuk tes hasil belajar. Pada saat implementasi observer mengisi lembar observasi keterlaksanaan kegiatan pembelajaran. Observasi dilakukan oleh dua orang guru matematika. Lembar observasi ini digunakan untuk mengetahui kelayakan RPP berdasarkan aspek kepraktisan. Hasil analisis lembar observasi keterlaksanaan kegiatan pembelajaran disajikan pada tabel 7.

Tabel 7. Hasil Observasi Keterlaksanaan Kegiatan Pembelajaran

\begin{tabular}{lcl}
\hline Pertemuan ke- & Presentase(\%) & Kriteria \\
\hline Pertemuan ke-1 & 75 & Cukup \\
Pertemuan ke-2 & 81 & Baik \\
Pertemuan ke-3 & 93 & Sangat baik \\
Pertemuan ke-4 & 94 & Sangat baik \\
\hline Rata-rata & 86 & Baik \\
\hline
\end{tabular}

Berdasarkan tabel 7, dapat dikatakan RPP sudah praktis karena rata-rata presentase keterlaksanaan pembelajaran model discovery learning sebesar $86 \%$ dengan kriteria baik.

Data keefektifan diperoleh dari hasil pretes dan postes diambil 36 peserta didik dari 108 peserta didik yang menjadi populasi, untuk materi pola barisan bilangan dan konfigurasi objek. Ketuntasan hasil belajar peserta didik disajikan pada tabel 8.

Tabel 8. Analisis Hasil Pretes Dan Postes

\begin{tabular}{lll}
\hline Ketuntasan peserta didik & Pretes & Postes \\
\cline { 1 - 2 } Kumlah peserta didik & 36 & 36 \\
Peserta didik yang tuntas & 13 & 27 \\
Peserta didik yang tidak tuntas & 23 & 9 \\
\hline Presentase ketuntasan & $36 \%$ & $77 \%$ \\
\hline
\end{tabular}

Berdasarkan tabel 8, terlihat peningkatan ketuntasan belajar. Sehingga dapat disimpulkan bahwa perangkat pembelajaran yang dikembangkan memenuhi aspek keefektifan.

Kajian produk akhir, pengembangan perangkat pembelajaran matematika dalam penelitian ini dilakukan sesuai dengan tahapan-tahapan dalam model penelitian pengembangan ADDIE, melalui tahapan-tahapan tersebut dapat diketahui kualitas dari perangkat pembelajaran yang dikembangkan, yaitu menggunakan kriteria kevalidan, kepraktisan, dan keefektifan sebagai tolok ukur Nieveen dalam (Haviz 2016). Berdasarkan hasil validasi ahli dan uji coba lapangan diketahui bahwa perangkat pembelajaran yang dikembangkan telah memenuhi kriteria valid, praktis, dan efektif ditinjau dari hasil belajar matematika berupa pretes dan postes.

Berdasarkan proses uji coba di lapangan, melalui hasil observasi keterlaksanaan pembelajaran menunjukkan bahwa keterlaksanaan pembelajaran termasuk dalam kategori "baik". Walaupun demikian, dalam proses pembelajaran, ada beberapa langkah yang masih sulit terlaksana berdasarkan 
pengamatan observer, seperti mengarahkan peserta didik untuk mau membaca, mencermati dan manelaah LKPD yang diberikan pada setiap pertemuan. Hal ini disebabkan masih rendahnya kemampuan berliterasi peserta didik dan materi yang diberikan mengharuskan peserta didik menginterpretasi pola-pola bilangan dan konfigurasi objek dengan masalah nyata. Hal ini membuat guru merasa perlu memberikan instruksi tambahan selain instruksi yang ada di LKPD.

Sementara efektifnya perangkat pembelajaran matematika dengan model pembelajaran discovery berbasis literasi numerasi, dalam proses pembelajarannya peserta didik diberikan beberapa pola atau konfigurasi dari beberapa objek dalam hal ini berkaitan dengan pola barisan bilangan, peserta didik mencermati dan membuat generalisasi dari pola-pola tersebut dengan kemampuan literasi numerasi.

Proses pembelajaran dengan model pembelajaran discovery berbasis literasi numerasi merupakan proses pembelajaran dimana peserta didik dapat menemukan sendiri konsep matematika yang baru dengan pengetahuan yang mereka miliki sebelumnya. Dengan menggunakan kemampuan literasi yang mereka miliki, mereka dapat membuat hipotesa dan membuktikan serta membuat generalisasinya. Hal ini menyebabkan pembelajaran matematika menjadi lebih bermakna, dan peserta didik lebih memahami materi/konsep.

\section{SIMPULAN DAN SARAN}

Pengembangan perangkat pembelajaran dengan model discovery learning berbasis literasi numerasi dilakukan berdasarkan model pengembangan ADDIE yang terdiri atas 5 tahap pengembangan yaitu analisis (analysis), perancangan (design), pengembangan (development), implementasi (implementation), dan evaluasi (evaluation). Perangkat pembelajaran dengan model pembelajaran discovery berbasis literasi numerasi ini layak digunakan ditinjau dari aspek kevalidan, kepraktisan, dan keefektifan.

Berdasarkan hasil penilaian RPP diperoleh rata-rata skor 4,3 dengan kriteria sangat baik. Sedangkan dari hasil penilaian LKPD diperoleh rata-rata skor 4,2 dengan kriteria baik. Sehingga perangkat pembelajaran dikatakan layak berdasarkan aspek kevalidan.

Dari hasil pengisian lembar observasi keterlaksanaan kegiatan pembelajaran, diperoleh ratarata sebesar $86 \%$. Berdasarkan hasil tersebut, RPP dikatakan praktis digunakan dalam kegiatan pembelajaran. Hasil pengisian angket respon peserta didik diperoleh rata-rata skor 3,6 dengan kriteria baik. Sehingga LKPD dikatakan praktis digunakan dalam kegiatan pembelajaran. Dari data tersebut pembelajaran layak digunakan berdasarkan aspek kepraktisan.

Sedangkan berdasarkan hasil pretes diperoleh presentase ketuntasan belajar 36\% dan hasil postes $77 \%$ dengan kriteria baik. Sehingga perangkat pembelajaran efektif untuk digunakan.

Perangkat pembelajaran dengan model discovery learning berbasis literasi numerasi dalam penelitian ini layak dari aspek kevalidan, kepraktisan, dan keefektifan maka sebaiknya perangkat pembelajaran yang dihasilkan dapat digunakan dalam kegiatan pembelajaran.

Uji coba perangkat pembelajaran menggunakan model discovery learning berbasis literasi numerasi sebaiknya dilakukan pada semua pertemuan untuk mendapatkan kualitas pembelajaran yang lebih baik lagi.

\section{PUSTAKA ACUAN}

Djamarah, and Aswaf Zain. Strategi Belajar Mengajar. Jakarta: PT Rineka Cipta, 2010.

GLN, Tim. Panduan Gerakan Literasi Nasional. Jakarta: Kemdikbud, 2017.

Haviz, M. “Research And Development; Penelitian di Bidang Kependidikan yang Inovatif, Produktif dan Bermakna." Ta'dib 16, no. 1 (2016).

Kebudayaan, Kementrian Pendidikan dan. Pengembangan Kurikulum 2013. Jakarta: Kemdikbud, 2013.

Kemdikbud. Panduan Gerakan Literasi Nasional. Jakarta: Kementerian Pendidikan dan Kebudayaan, 2017.

Pangesti, Fitriyaning Tyas Puji. "Menumbuhkembangkan Literasi ." Indonesian Digital Journal of Mathematics and Education Volume 5 Nomor 9, 2018: 573.

Rusman. Model-model Pembelajaran. Jakarta: Rajawali Pers, 2013.

Salmon, A, et al. Belajar dan Pembelajaran Discovery Learning . Ambon: Makalah Universitas Patimura Ambon: tidak diterbitkan., 2012.

Sugiyono. Metode Penelitian Kuantitatif Kualitatif dan R\&D. Bandung: Alfabeta., 2015.

Virgana, V. "Stad Problem Solving Minat dan Pemahaman Konsep." Faktor Jurnal Ilmiah Kependidikan 3, no. 3 (2016). 